\title{
AN EXPLORATION OF CAUSES FOR DELAY AND COST OVERRUNS IN CONSTRUCTION PROJECTS: CASE STUDY OF AUSTRALIA, MALAYSIA \& GHANA
}

\author{
Raj Kapur Shah
}

\author{
Senior Lecturer, Department of the Built Environment, Faculty of Technology and Environment, \\ Liverpool John Moores University, Liverpool, L3 3AF, United Kingdom \\ Email Address: r.shah@ljmu.ac.uk
}

\begin{abstract}
Cost and time overruns are the key problems of any construction projects. These issues are causing the negative impact on the development of country economic growth and prosperity. To overcome these issues, the paper is aimed to discover the most influence factors causing the project delay and cost overruns and recommend the possible measures by investigating case studies in three different countries in the world. Each country's quantitative data from the past studies was selected to analyse and recommend the effective measures. A questionnaire survey was conducted in all three case studies adopting different data collection strategy. The reason of selecting three case studies is to outline the compare analysis of delay factors and to classify why different delay factors have different priority level of influence in project delay from one country to another country. The findings from the case studies exposed that the most influential factors in Australia are (1) planning and scheduling deficiencies, (2) methods of construction, (3) effective monitoring and feedback process, whereas in Ghana, (1) delay in payment certificates (2) underestimating of project cost, (3) complexity of projects are the most influential factors. However, in Malaysia (1) Contractor's improper planning, (2) poor site management, (3) inadequate contractor experience are the most influential factors. This paper has also analysed the average and least impact of the delay factors causing project delay and cost overruns in those countries. The paper concludes that there are diverse groups of delay factors from one country to another country that causing project delay and cost overruns. It also concludes that there are diverse measures according to the nature of delay factors to reduce the impact on project delay and cost overruns in construction industry.
\end{abstract}

Keywords: Cost and time overruns, delay factors, construction industry, projects delay, and developing countries

\section{Introduction}

Construction delays are more likely to happen in almost all projects due to the miscommunication between contractors, subcontractors, property owners or any other reasons. In many cases, construction projects are delayed because of inaccurate estimate of time and project cost that was initially presented to the clients or project owners. Delays and cost overruns are the most common problems causing delay in the construction industry in both developed and developing countries (Enshassi, 2009). A study by Flyvbjerg (2003) exposed that nine out of ten projects had the cost overruns from a sample of 258 companies across 20 countries and 5 continents around the world. In practice, delays occur in every construction project and the magnitude of these delays varies significantly from project to project and country to country (Wael et al, 2007).

Construction industry plays an important role in contributing on national economy around the world (Takim, 2005). The construction industry also impact the rate of GDP and employment of many countries, and for this reason, the construction industry is considered to be vital for the economic growth of a country (Olawale, 2010), and he suggested that the construction activities have become a significant market indicator since this industry produces more products and consume more materials than other industries. The cost overrun is one of the critical problems and requires a lot of research studies and exploration to minimise or reduce the delay and less variation in budget for the future 
projects. In some of the developed countries, the cost overruns consequence could be more serious and the results could sometimes exceeds $100 \%$ of the initial project estimated (Angelo, 2002). The construction industry is one of the main sectors to stimulate and provide ingredients for the improvement of a country economy. Therefore, it is considered that the construction has a great connection and play significant roles in the economic growth or reactivation in all countries.

Delays are constantly occurring in road construction projects and they could causes great impact on economic growth. It is one of the common problems that upset the construction companies in terms of competitiveness and long term sustainable in the global market. Due to the population growth, industrialisation and urbanisation, more roads and highways are required for the easy access to market, economy and other vital purposes such as transportation and delivering goods and services (Mahamid, 2012). He highlights that cost is one of the major issues which has to be considered throughout the project life cycle and it can be considered as one of the most important factors cause the project to delay and failure if appropriate consideration is not taken into account. The issue of cost overrun in project is attracting more researchers over the past decades and still more research are running to address the issue.

Moreover, there are many risk factors causing cost overruns in the construction industry, therefore, researchers tend to take this issue into further scrutinise with aim of identifying the factors and their ranking of importance. In recent study, researchers have tried to discover the reasons behind the initial estimated and final amount, and other causes of time overrun. Morris (1987) found four key factors that were the most likely influenced on cost overruns. These factors include design changes, poor planning, unpredictable weather condition and the fluctuation in prices of building materials. It is important to have in depth understanding of the outstanding issues in the construction industry. Hence, the paper aims to provide in depth light about the existing causes of project delay and cost overrun in both developed and developing countries, and outline the possible recommendations for controlling project delay and cost overruns in future projects by analysing the case studies from different countries.

\section{Literature Review}

Kaming et al (1997) conducted a study on thirty one high rise projects in Indonesia, and the study revealed that the cost overruns are more likely to occur than time overruns, which means that the issue of cost is more important and common than the project delay. He found that majority of the problem causing cost overruns are due to increase in material prices and currency inflation, whereas the delay in time was due to inaccurate estimation, design changes, poor labour productivity, inadequate planning, and shortages of necessary resources. Similarly, a survey was conducted by Assaf (2006) and identified a total of fifty six main risk factors, which were more likely to cause the project delay. Delay factors are grouped into nine major factors in terms of their level of importance to different parties. Howick et al (2009) stated that construction projects can suffer massively in time and cost overruns because of mainly two reasons: to gain learning for future projects, and to claim compensation from one to another party during the project.

Moreover, a survey was conducted by Greenwood et al (2005) aimed to find the subcontractors liability in project delay. They found that despite the level of importance of agreement between the two parties, there is advantageous way of dealing with such delays and that could be subjected to Liquidated Damage. The survey also found the most common method for dealing with such delay liability in subcontract is to base damage upon proportion of main contract liquated damages (LD). The delay in subcontractors delay has to be dealt with before the start of the project, by agreeing to 
the terms in both sides. Having an appropriate planning scheduling can decrease a significant number of potential reasons for project to be delayed as the scheduling gives clear indication how a project and people are performing, since appropriate scheduling tells when an activity should be finished whereas on the other hand, effective monitoring will ensure that particular activity finishes in its estimated time, this will show the project is working according to the plan and the next activity will start without any delay. All of these three important factors have to be considered and advanced procedures to be used to avoid controlled delay.

Furthermore, a study conducted by Assaf (2006) found that any changes made by client during the construction period would affect in progress payment by client. Other causes are improper planning and scheduling of projects by contractor, poor site management and supervision by contractor, shortage of labour, difficulties in financing project by contractor. This shows that changes made by client while construction is already in progress will not only slow the progress but also affect everything that contractors has planned for the project in terms of materials delivery schedule or any activities that were due to finish on time. Such changes made by client could stop the work and increase project cost and delay the delivery schedule. The cost and time overruns are the two common factors frequently occurring within the construction projects. The past project history shows that the construction industry has vast number of projects were completed with time and cost overrun (Amehl, 2010). In addition, Al-Momani (1996) suggested that the actual estimated cost of project rises by up $30 \%$ by the time the project is ready to be completed even in the most developing countries.

Noulmanee et al (1999) has investigated the causes of delay in highway construction in Thailand and the survey result showed that the delay are caused by all parties were involved in the project, even the main reason was due to inadequacy of sub con tractors, organisation not providing required resources, unclear drawing and lack of communication between consultants and contractors. Noulmaneeet al (1999) suggested that delay can be minimised by better understanding and involving all parties in the project with good communication between them. Similarly, a survey was conducted in Lebanon by (Mezher, 1998) and he found that the owners were more wary of their financial issues, contractors were not very keen about their relationship with other parties, and there was a lack of trust in guaranteeing and complying with the agreement. But it was found that the poor management by consultants was key reason of the delay. There were three main causes of cost overruns identified by(Koushki, 2005) in a study in Kuwait, which include contractor related problems, material related problems and owners' lack of experience.

Ellis (2002) conducted a study to investigate main causes of delay in highway construction projects. The study was split into two categories: excusable and non-excusable delay and found that on average $31 \%$ to $55 \%$ of all highways experienced a delay of $44 \%$ extra from the original agreed period. The study also highlights that the delay mainly occurs more frequently in the urban areas. Similarly, Jahren (1990) discovered that the quality of the contractor document, nature of the interpersonal relation on the project and the policies of the contractor were key factors causing a significant impact on cost overruns. The same investigation also exposed that a cost overrun rate from $1 \%$ to $11 \%$ are more likely to occur on larger construction projects than smaller ones.

Moreover, a significant number of researchers have been involved in identifying causes behind the delay in the construction projects and a lot of work has been carried to minimise such problematic issues occurring in almost every project in every country worldwide. Six outcomes of delay were identified by (Sambasivan, 2007) which comprise of time overruns, cost overruns, disputes, arbitration, litigation and total abandonment. In many occasion, the delay happens due to human errors and careless attentions to facts from either client or other team members of staff. Sibanyama 
(2012) suggested that difficulty of establishing fair and expeditious settlement of claims depended on untimely notification, poor record keeping, inadequate legal and factual justifications and poor presentation. It is vital for contractors to fully understand the client's requirements and fully commit in providing services accordingly.

Furthermore, some authors believe some of the factors causing delay or cost overruns can be classified as understandable and other parties should understand the situation of others where they believes cost overruns due to their inaccurate estimation. Similarly, Chan (2002) identified other reasons causing cost overruns and classified them into 3 aspects such as owner's control, consultant's control, and beyond the control. Whereas, Bramble (1987) classified major delay factors into four categories: excusable or non-excusable delay, compensable or non-compensable delay, critical or noncritical delay, and concurrent or non-concurrent delay. Excusable are those delay arising from the outside the control of the parties to the project such as acts of God where an unexpected weather occurs or a strike action by labour, there are nothing can be done about such delays. Non-excusable are those delays that one cannot have any excuse or can provide an excuse because the delay occurred within due to careless of the contractor or consultant for slow progress. Compensable delays are those delays where contractors and subcontractors have legal right to get a time extension from the agreed finishing date of completion as this occurred due to the owner's requirement change of plan, and they're entitled to additional financial compensation for the cost of delay. Nonetheless, Yates (2006)suggested that non-compensable delay occurs due to acts of God where the fault are not from any parties and therefore, the contractor is entitled only to extension of time but not additional cost.

\subsection{Factors affecting project cost and time overruns}

Construction is considered as an active industry and therefore delay in the construction project has been one of the main subjects for many researchers. Delay is one of the major risk factors for both contractors and owners and causes difficulties within the project and then leads to cost and time overruns. Chan (2004) highlighted that the cost overruns to be one of the most critical issue at the execution stage of the construction project. Also stated by (Van Der Westhuzien, 2005), the presence of cost overruns can be a reason behind the failure of a project. But not all authors agree that the failure is viewed from one single factor but many believe there are a significant amount of factors causing the delay. However, Morris (1987) suggetsed that there are three different measures to identify whether, the projects is successful or not. Project should perform functionality, management of the project and performance of the contractors during the process. In the other hand, Chan (2004) suggested that the key to a successful project completion and deliver is correct estimation, monitoring time performance, cost performance and the overall quality of the construction project.

\subsection{Delay in the developed countries}

The delay and cost overrun are also key issues in the developed countries. For example, Bourn (2003) published a report entitled "Modernising construction" and highlighted that $70 \%$ of the UK construction projects, which are carried out by public departments and agencies, are delayed. A research conducted by Building Cost Information Service (UK) found that nearly $40 \%$ of the construction projects overrun the originally agreed contract period. Similarly, a survey was carried out by Mansfield (1994) amongst contractors, consultants and clients in Nigeria and he found a total of 16 factors causing the project delays and cost overruns, whereas some of critical risk factors were finance arrangements for payment, poor contract management, shortage in materials, inaccurate estimation and price fluctuation. Moreover, Arditi (1985) conducted a survey amongst 146 organisations in Turkey and he found that the main reasons causing the cost overruns are the increase in materials' 
prices due to fast growth of Turkish inflation. The increase in inflation then made it difficult for contractors to buy materials at official prices which they have already estimated at the beginning or prior to the project, and that also affected in selling their products at the estimated prices. This fact was considered as the most important reason for cost overruns. Furthermore, a shortage in resources, changes in design specification and financial problems were the other reasons for the cost overruns and project delay. Finally, the fifth reason was underestimation of the project cost at the time of setting the budget. Arditi (1985) ranked the main causes for delay and cost overruns in construction projects found in Turkey as follows:

1. Increase of materials' prices

2. Fast growth of inflation

3. Inflation increase causes contractors to produce products at the agreed price.

4. Delays caused by changes in design specification and financial problems.

5. Underestimation of project cost when setting the budget of the project

\subsection{Delay in the developing countries}

According to Rabbani et al (2011), the most common factors that cause the construction delay in Pakistan are external factors due to natural disaster such as earthquake and floods. Similarly, Bramble and Callahan (2010) found that unexpected problem such as act of natural phenomenon also causes the project delay. Other factors causing delay in Pakistan are financial payment issues, poor planning, poor site management, lack of experience and shortage of materials and equipment. In other hand, the main reasons for delay in Saudi Arabia are due to the lack of qualified man power in the industry (AlKharashi, 2009). In another study by (Sriprasert, 2000)highlighted that the main reason of project delay and cost overruns is the lack of capability of controlling the construction processes in Thailand.

Moreover, the construction projects varies in terms of complexity in nature, location, type of contract, communication between parties, and less experienced people in such situation can have significant risks to project delay and cost overrun (Ahmed, 1999).In a study done by (Kaming et al, 1997) found that contractors agreed that, the main factors causing delay and cost overruns in Indonesia are due to improper estimation for material take-off and price inflation due to environmental restriction. Performance of the construction project plays an important role in delay and has significant impact on the time scheduled for the project. Ajanlekoko (1987) conducted a research in Nigeria and found that the construction industry's adherence to the contract schedule was very low. Similarly, a number of researchers such as (Ogunlana, 1996;Al-Momani, 2000; Frimpong, 2003 and Chan, 1997) have carried similar survey in their chosen country and they found that the delay in the construction projects is inevitable depending on the geographical location and nature of the construction project.

A study was conducted by Battaineh (1999) within164 buildings and 28 highway projects constructed in Jordan during the period of 1996-1999, and he revealed that the actual completion period increased by $160 \%$ in road construction projects and $120 \%$ in building projects compare to the initial estimated time. This is because of the project complexity in nature and varies from one location to another location geographically in the world and the issues of delay and cost overruns are common, particularly in the construction projects in the developing countries. Moreover, Assaf (2006) conducted similar study in the Saudi Arabia and he exposed that only $30 \%$ of construction projects were completed on time and $70 \%$ project were delay whereas the cost overrun was between $10 \%$ and $30 \%$ which leaves a significant proportion of delay in the country. This can be seen as major factors in 
the most developed country in the Middle East. Past statistics showed that majority of projects are not delivered on time and in the agreed budgeted cost at tender stage in the construction industry. The next section describes about the research methodology adopted in the study.

\section{Research methodology}

There are different approaches to conduct research but the qualitative and quantitative are common, which are used regularly and widely in the build environment sector for analyse purposes. Therefore the research approach adopted in the study is a quantitative approach in order to identify the causes of delay and cost overruns so that the impact from these causes could be reduced by taking proactive actions. Punch (2005) suggested that research approach depends on the research questions prepared for the study, whereas Rea (2012) explained that there is no better approach to a quantitative research study than a survey for collecting information amongst large population. The quantitative data from the case studies using tables, graphs and figures is helpful to examine and interpret them more effectively.

The quantitative approach is used in the study, which is based on the secondary data and this was collected from the past publications for further analysis. In this approach, mainly a survey was conducted by designing a questionnaire and distributing them to the targeted respondents randomly before collecting and analysing them to draw the findings from the survey. The purpose of using case study is to get in depth understanding with their data that and explore the data for further analysis so that a comparative analysis of their similarities and the uniqueness of each project could be presented. There are many causes for the cost overrun and delay in construction industry and different areas could possibly have different reasons of delay, therefore, it's important to understand causes of delay around the world. Analysing their data assists to provide a better understanding of the reasons of delay and a suitable recommendation for future project and different scenarios. This is also helpful to identify the possible measures in order to reduce the impact of delay and to give something to be considered for the upcoming events. Therefore, the analysed data gathered from secondary sources to be used as quantitative data for acquiring further understanding of the dilemma and directing to a better path.

\section{Case studies and data mining}

For the comparative analysis and depicting the findings, three case studies of construction projects were selected from Australia, Malaysia and Ghana considering developed and developing countries around the world. Each country has uniqueness in dealing with construction and businesses, therefore, many countries have different reasons causing the project delay and cost overruns. Hence, identifying causes of delay in each country separately augment better understanding for future warning and proactive actions to be undertaken in future project. Analysing different countries around world also provide a vision to see which factors are common and why such factors are ranked as the highest threat in delaying the construction projects and cost overruns. The delays in road construction project have brought the attention to the community to why such incident always occurs and why time estimated by consultant does not meets the deadline. Since this is one of the most common and frequent problem in the construction industry, many researchers have studied and discussed for decades but the delays still happens in almost every construction project. The delay could have different reasons as for the project various from project sizes, locations and the scope of the projects. Some of the project happens to be late for few days and some could be delayed for years from the estimated time. Many researchers have studied this problem within the construction industry but it is 
vital to identify all possible causes of delay in order to bring a solution to reduce the impact from delay in the future construction projects.

\subsection{Delay and cost overruns: A case study of Australia}

An investigation was carried in Australia about cost overruns and failures in construction project management. The purpose of this research was to get a clear understanding of the current performances regarding the cost and management issues and can obtain clue about the critical factors having impact on the cost overruns in the construction industry. The methods was used questionnaire survey, the aim of this method was to obtain some data from consultants, and contractors, who have experience in construction. Over 160 responses from clients, consultants, and contractors were selected based on their background, experience and active participation in the construction industry. Clients, consultants and contractors play key role in a construction project and the non-excusable types of delay are usually related to the inaccuracy of their responsibilities, therefore, it is extremely important to interview them and investigate their responses and analyse them to give a better understanding and to determine from their experience what are factors causing project delay and cost overruns in the construction projects. General information about the respondents who participated in the survey is shown in Table 1 below.

Table 1 General information of respondent and questionnaire (Source: Doloi, 2013)

\begin{tabular}{|c|c|c|c|c|c|}
\hline $\begin{array}{c}\text { Field of } \\
\text { work }\end{array}$ & $\begin{array}{c}\text { Respondents } \\
(\%)\end{array}$ & $\begin{array}{c}\text { Experience } \\
(\text { years })\end{array}$ & $\begin{array}{c}\text { Respondents } \\
(\%)\end{array}$ & $\begin{array}{c}\text { Project budget } \\
(\mathbf{\%})\end{array}$ & $\begin{array}{c}\text { Respondents } \\
(\%)\end{array}$ \\
\hline Clients & 25 & $<1$ & 2 & $<5$ & 2 \\
\hline Consultants & 31 & $1-5$ & 16 & $5-25$ & 8 \\
\hline Contactors & 44 & $5-10$ & 36 & $25-75$ & 20 \\
\hline & & $>10$ & 46 & $75-150$ & 59 \\
\hline & & & & $>150$ & 11 \\
\hline
\end{tabular}

\section{Findings}

The total numbers of 100 out of 160 responses were collected from clients, consultants and contractors in Australian construction industry. The table above represents their responds in respect to their career history and the size of the project they are involved in terms of budgets. The table shows that almost half, $46 \%$ had at least 10 year or above experience and only $2 \%$ had less than one year experience in the construction industry which means over half $52 \%$ have at least 1 to 10 year experience. The last column in the table shows the percentage of budgets which can be found that the budgets between $\$ 75$ to $\$ 150 \mathrm{~m}$ tops the table with $59 \%$ and only $2 \%$ are less than $\$ 5 \mathrm{~m}$ and the second highest $20 \%$ in the range of $\$ 25$ to $\$ 75 \mathrm{~m}$, whereas $11 \%$ of the respondents shows their budget were over $\$ 150 \mathrm{~m}$.

\section{Data analysis}

There are many ways in analysing the collected research data. The researcher have used Relative Importance Weight (RIW) technique for ranking the critical factors since it is widely used in quantitative analysing, particularly in build environment (Chan, 1997). The researcher organised questionnaire in the form of importance scale, by asking contributors to tick columns which indicates its relative importance of each of the cause construction in terms of contestant expressing the weight ( $5=$ very low, $4=$ low, $3=$ medium, $2=$ high and $1=$ very high). The RIW score is a useful measure of the relative positioning of a particular attribute perceived by the respondents on the raw dataset (Chan, 1997). The RIW method was used in this research is as follows: 
$R I W=\frac{\sum_{i=1}^{5} a_{i} n_{i}}{\sum_{j=1}^{N} x_{j}} \times 100$

A survey conducted by Doloi (2013) using a questionnaire survey and found48 attributes/factors were identified associated to client, consultant and contractor causing poor performance management in construction industry in Australia (for details of factors see appendix-A). This study was aimed to find what causes influence on cost performance. It was revealed that planning and scheduling were ranked at number 1 of the list making it the most critical factor causing poor performance. The second and third factors are methods/techniques of construction process and effective monitoring/feedback process which seem all three factors are related with the proper management. The two factors ranked in the middle of the table are delay in subcontractors' project and lower labour productivity. The list of most significant factors casing delay and cost overruns were listed that need to be considered in a construction project (see appendix-A).

\subsection{Delay and cost overrun: A case study of Ghana}

Construction industry in Ghana plays an important role of providing and boosting country economy according to Ghana Statistical Service in 2007. The construction industry contributed in the national economy was $8.5 \%$ of GDP. Any construction projects being subjected to delay can have significant impact on the overall income of the project, therefore, it is vital to ensure the construction industry is performing well and brings good service to the government and business sectors. As Ghana is planning to immense their economy in order to become a middle income nation which was due by 2015 and their recent discovery in oil fields in the commercial quantities boost the target. Governments across the world are investing a vast amount of money in identifying a solution for eliminating or minimising the impacts from factors that causing project cost and time overruns in the construction projects.

\section{Findings}

A study was carried out in order to identify major factors causing delay in building construction projects in Ghana. The researcher used questionnaire survey approach in identifying and understanding the reasons behind the delay in construction industry and perceptions of the three main parties who play main roles in this industry so that possible ways in minimising the impact on delay and project cost variation could be identified. The researcher believed the delay is one of the major problems facing in Ghana and this issue is growing since the delay is happening in regular basis in Ghanaian construction industry. Therefore, the research found a gap in this study. But the gap still exists in many construction projects worldwide, where appropriate planning has been undertaken to ensure the project would be finished on time and within budgeted cost but unluckily the delay is happening in almost every project and consequently overrun the project cost.

Table 2: (Source: Fugar, 2010)

\begin{tabular}{|c|c|c|c|}
\hline Respondents & $\begin{array}{c}\text { Questionnaire } \\
\text { distributed }\end{array}$ & $\begin{array}{c}\text { Responses } \\
\text { returned }\end{array}$ & $\begin{array}{c}\text { Percentage of } \\
\text { responses }\end{array}$ \\
\hline Client & 55 & 37 & $67 \%$ \\
\hline Consultants & 55 & 39 & $71 \%$ \\
\hline Contractors & 55 & 54 & $98 \%$ \\
\hline Total & 165 & 130 & $79 \%$ \\
\hline
\end{tabular}




\section{Discussions}

The researcher has used the Relative Importance Index (RII) to identify top critical factors causing the delay. The questionnaire was prepared and sent to the three main categories: client, consultant and contractors in the form of the importance scale by indicating to tick a column of the relative importance of each cause of delay. A total number of 165 questionnaires were distributed, as shown in the table but response rate was $79 \%$ (only 130 response were received) and use these responses for analyse. Each response represents importance in terms of $(4=$ very important, $3=$ important, $2=$ somewhat important and $1=$ not important).

The survey results showed in table (for details see appendix-B) that a total of 32 possible cause of delay were identified. The results showed that "delay in honouring payment certificates" are the top most delay factors and they have all agreed this factors as a prime cause of delay. The issue of late payment is very common in non-developed countries. Another study in Malaysian construction industry also justify that the impact of the late or non-payment to contractors result the delay in the progress of the project or they might force to abandon the project. Therefore, paying everyone involved in the project on time could improve the chance of project finishing on time.

The second factor "underestimation of cost of projects" was highly ranked by client, whereas, consultants have ranked this at their number 3 in their importance factor (see appendix-B). In contrast, contractors have only ranked this issue at number 5, which could be the reason that contractors are those to estimate cost and therefore they don't want to blame themselves for it. And again the same case applies to the third ranked factor which is the "underestimation of complexity of projects", which consultants ranked at number 3 and at number 8 by contractors because they don't want this factor to be in the higher ranks. The mid table factors (see appendix-B) are "poor design and breakdown of equipment". This reflects that Ghana doesn't seem to be facing any major problem with construction design planning which means the place where this factor is ranked as a good place considering other factors. The least factor to cause delay in Ghana was shown in the table (appendix-B) was "Public holidays", the fact that this does not impact on the delay due to the acknowledgement of the holidays before hands. However, when an agreement is done between parties, the public holiday has already been considered and time is considered to be longer, therefore, public holidays can't be an issue or an excuse when a construction is delayed.

\subsection{Delay and cost overrun: A case study of Malaysia}

The cost and time overrun is a global issue and it is happening in every part of the world and every country but yet the problem still exists and happens for various reasons. In 1991, Malaysian Government introduced a vision for a strong and better industrialisation in economy. The proposed vision was called "Malaysian Vision 2020", by defining a clear path for making Malaysia one of the developed nations. The main purpose of this vision was to transform the country into competitive and dynamic resilient by the year 2020. Ever since the construction industry sector play a significant role since this industry can provide better contribution in national economy and GDP growth. Therefore, construction industry has to be very effective in terms of delivering project on time without vitiating any loss and the industry must perform appropriate, and finally the country must compete with other developed nations in the world with aim of accomplishing the vision and mission. The construction industry has developed in Malaysia, but just like many other countries in the world but the projects are facing major loss from time and cost overruns. To better understand this matter and find a solution, a questionnaire survey was undertaken to find out what are the project facing with cost performance to be analysed and looked at. 


\section{Findings}

In this case, the researcher has also used Relative Importance Index (RII) method to identify their importance of causes and effect of delay factors, which is also used by Kometa (1994). The questionnaire was send to three groups (clients, consultants and contractors) who play main roles in construction projects. The same method was also used in Ghanaian construction industry survey, where the scale is used ranging from 1 being not important and 5 very important. The (RII) was used to identify which cause are the most significant causes by ranking them into their RII importance values. A total number of 150 respondents participated in the survey in which ten were identified the most effective factors causing delay and cost overruns from the list of 20 (Soon, 2007). The top 10 most important factors, which found from the survey in Malaysia construction industry, are as follows:

1. Contractor's improper planning

2. Contractor's poor site management

3. Inadequate contractor experience

4. Inadequate client's finance and payments for completed work

5. Problems with subcontractors

6. Shortage in material

7. Labour supply

8. Equipment availability and failure

9. Lack of communication between parties

10. Mistakes during the construction stage

\section{Discussions}

From survey results, it clear that the primary reason for the delay is the lack of appropriate planning in the construction project followed by poor site management. What can also be seen is that the pressure is more on contractor than clients or consultants. This could be the result due to the fact they want to blame other people responsible for the delay. In contract, the contractor is also blaming subcontractors which confirm the communication between the parties is not in a professional way and each want to blame each other for delay. Contractors seem to have insufficient experience within the industry which could cause the project to perform well and could slow the progress as a result of it. The fourth most critical factor is "Inadequate client's finance and payments for completed work" which is vital in any construction project because late payment always slow the progress or could make them to abandon the project. In other cases, where the project is completed and the payment's still due, the company can lose its reputation and make it harder for other to cooperate with them in the future.

\subsection{Outcomes from case studies}

The available data and information acquired from the past studies illustrates that the key factors of causing the project delay varies from one country to another country. For example, in Ghana the most critical factor and threat to the project delay is the delay in payment which could have significant impact on the project progress and its performance in terms of quality and services. In contrast, Australia and Malaysia share the most of critical factors are similar. For example, the lack of planning and scheduling by contractors would affect the estimated targets within the agreed budget and the consequences of this could result in project delay and cost overruns. The $2^{\text {nd }}$ most factored causes placed in Ghanaian ranking is underestimation of the project cost, This factor is more frequent in the undeveloped country or a country in the process of developing in the construction industry and the reason for underestimating the cost is might be due to the price inflation in the country or lack 
unavailability of materials and time variation could also change materials prices. However, in Malaysia and Australia, poor site management and ineffective construction techniques are ranked as $2^{\text {nd }}$ most influential factor for delay project.

One of the common factors shared in both Ghana and Malaysia, which ranked in $3^{\text {rd }}$ place, is the lack of contractor's experience in the construction industry and underestimation of the complexity of the project. In general, these two factors are related to one another in terms of improper management of project. The project manager must be someone having experience in similar industry to forecast possible causes from beginning to the end of a construction project in terms of dealing with all aspects including subcontractors and owner and to deal with it in appropriate manners when arise any such incidents. If someone with sufficient experience is appointed to be the project manager for a project, they are more like to organise better by analysing the complexity of the project with aim of accomplishing them in the efficient way. In contrast, $3^{\text {rd }}$ ranked factor in Australia is related to the poor site management. What Malaysia is also lacking behind the developed countries is the insufficient payment from the client and payment after the work is completed, but Australia must be handing work to someone with adequate experience in construction industry in order to find an appropriate way of handling complex design. Whereas Ghanaian government needs to find an easy way of accessing credit from bank as delay in payment in that country is ranked number influence of factors causing delay.

\section{Conclusions and recommendations}

In conclusions, it is found that three case studies used in the paper adopted the questionnaire survey as an approach to collect research data and understand the questions of delay in the construction projects in both developed and developing countries. The survey results found that the most critical factors causing delay and cost overruns and ranked them from the most to least influential factors using RII method. The study exposed that some delay factors are more critical than others in regards to the geographical location and political issues from the government to the local contractors, consultants and clients.

Moreover, the project delay is still happening and will continue to happen in the construction for various known and unknown reasons such as unexpected factors, bankruptcy from client, changes in design during the construction, political issue, sudden price fluctuation, severe weather conditions and change of circumstances with projects manager in result of forcing him/her to leave before completing the assigned job. However, time and cost overrun may not be prevented entirely but the evolving new technology like BIM, new methods and past experience could be used to reduce the impact from recognised risk factors, particularly in the undeveloped and developing countries. Finally, the paper concludes that it is important to evaluate the critical delay factors and take necessary proactive actions at early stage of project and before preparing the execution plan so that the project delay and the cost overruns could be minimised in future construction projects. The top three critical factors found in three different countries are shown below that could be useful when analysing the delay and cost overrun in future projects.

Table 3

\begin{tabular}{|c|l|l|l|}
\hline S.N. & \multicolumn{1}{|c|}{ Australia } & \multicolumn{1}{c|}{ Malaysia } & \multicolumn{1}{c|}{ Ghana } \\
\hline 1 & $\begin{array}{l}\text { Planning and scheduling } \\
\text { deficiencies, }\end{array}$ & $\begin{array}{l}\text { Contractor's improper } \\
\text { planning }\end{array}$ & $\begin{array}{l}\text { Delay in payment } \\
\text { certificates }\end{array}$ \\
\hline 2 & Methods of construction, & $\begin{array}{l}\text { Contractor's poor site } \\
\text { management }\end{array}$ & $\begin{array}{l}\text { Underestimating of } \\
\text { project cost, }\end{array}$ \\
\hline 3 & $\begin{array}{l}\text { Effective ways of } \\
\text { monitoring \& feedback }\end{array}$ & $\begin{array}{l}\text { Inadequate contractor } \\
\text { experience }\end{array}$ & $\begin{array}{l}\text { Underestimating the } \\
\text { complexity of projects }\end{array}$ \\
\hline
\end{tabular}


The paper also recommends that following the most important factors must be considered and analysed in depth about its impact on project time and cost prior or during the execution of a construction project.

1. Proper planning and scheduling throughout the construction project.

2. Effective programming in order to keep track of each activity and its time of delivery.

3. Material price's must be checked regularly before/after estimation and before purchase.

4. Estimation of cost and design must not be undertaken easily.

5. Use effective methods to visualise the overall project view such as (BIM technology).

6. Establishing appropriate communication with all parties (collaborative BIM).

7. Ensure labour and contractors are paid on time and ensure site health and safety.

8. Monitoring the work is essential but motivating the team is important for a successful project.

9. Weather condition should be checked and monitored in advance.

10. Regular meetings with subcontractors and suppliers.

\section{References}

1. Ahmed, S. M., Ahmad, R. and De Saram, D. D., "Risk management trends in the Hong Kong construction industry": a comparison of contractors and owners perceptions. Engineering Construction and Architectural Management, 6: PP 225-234. (1999)

2. Ajanlekoko, J. O., “Controlling Cost in the Construction Industry”, Lagos QS Digest, Vol. 1 (1), pp. 8-12, (1987)

3. Al-Kharashi, A. and Skitmore M., "Causes of delays in Saudi Arabianpublic sector construction projects", Construction Management and Economics, pp. 3-23, , (2009)

4. Al-Momani A., "Construction cost prediction for public school buildings in Jordan", Construction management and Economics, Volume 14, pp. 311-317, (1996)

5. Al-Momani A. H., "Construction delay: quantitative analysis" International Journal of Project Management, pp. 18 (1), 51-59, (2000)

6. Amehl, O.,Soyingbe, A. And Odusami, K., "Significant factors causing cost overruns in telecommunication project in Nigeria". Volume 15(2), pp 49-67, (2010)

7. Angelo, W. J. And Reina, P., "Megaprojects need more study up front to avoid cost overruns", Vol 243 (3), McGraw-Hill, New York USA, (2002)

8. Arditi, D.,Akan, G. andGurdamar, S., "Cost overruns in public projects. Internal journal project management”, Vol. 3 (4), pp. 218-224, (1985)

9. Assaf S.A. and Al-Hejji, S., "Cause of delay in large construction project", International Journal of Project Management, Vol 24 (4), pp. 349-357, (2006)

10. Avots, I., "Cost-relevance analysis for overrun control", International Journal of Project Management, Vol 1(3), pp. 142-148, (1983)

11. Battaineh, H., "Information system of progress evaluation of public projects in Jordan", MSc thesis, Civil Engineering department, JOrdan university of science and technology, (1999)

12. Bourn, J., "Modernising construction", A report published by the National Audit Office, (2003)

13. Bramble, B. B. And Callahan, M. T., "Construction Delay Claims", $4^{\text {th }}$ Edition, USA: Wolters Kluwer Law \& Business, (2010) 
14. Chan, A., Scott, D., and Chan, A., "Factors affecting the success of a construction project" Construction Engineering and Management, Vol 130 (1), pp. 153-155, (2004)

15. Chan, D. W. M.and. Kumaraswamy, M. M., "A comparative study of cause of time overruns in Hong Kong construction project”, Int, J. Project management, Vol. 15(1), pp.55-63, (1997)

16. Greenwood, D., Hogg, K. and Kan, S., “Subcontractors' libility for project delay”, Journal of Financial Management of Property and Construction, Volume 10 (2), pp. 107-114, (2005)

17. Doloi, H., "Cost Overruns and Failure in Project Management", Journal of construction engineering and management, Vol 139 (3), pp. 267-279, (2013)

18. Ellis, R. D. and Thomas, H. R., "The root causes of delays in highway construction", Washington DC.: $82^{\text {nd }}$ Annual meeting of the transportation research board, (2002)

19. Enshassi, A., Al-Najjar, J. andKumaraswamy, M., "Delays and cost overruns in the construction projects in the Gaza Strip", Journal of Financial Management of Property and Construction, Vol 14 (2), pp. 126-151, (2009)

20. Flyvbjerg, B. Skamris, M.K. and Buhl S. L, "How common and how large are cost overruns in transport infrastructure projects?” Transp. Rev, Vol 23 (1), pp. 71-88, (2003)

21. Frimpong, Y. Oluwoye. J. and Crawford, L., "Cause of delay in construction goundwater project in a developing countries”, Ghana case study. Int. J. Proj. Management, 21, pp. 55-63, (2003)

22. Fugar, F. D. K. and Agyakwah-Baa, A. B., "Delay in building construction projects in Ghana”, Journal of Construction Economics and building, Vol 10 (1), pp. 103-116, (2010)

23. Jahren, C. andAshe A., "Predictors of cost overrun rates", Journal of Construction Engineering Management ASCE, Vol 116 (3), pp. 548-552, (1990)

24. Kaming, P., Olomolaiye. P., Holt. G. D. and Harris. F., "Factors influencing construction time and cost overruns on high-rise projects in Indonesia", Construction Management Economics, Vol 15 (1), pp. 83-94, (1997)

25. Kometa ST, O. P. H. F., "Attributes of UK construction clients influencing project consultants' performance”, Construction Management Economy, p. 433-43, (1994)

26. Koushki, P. A., Al-Rashid, k. and Kartam, N., "Delay and cost increase in the construction provate residential in Kuwait”, Construction Mang\& Economics, 23, pp. 285-294, (2005)

27. Sambasivan, M. and Soon, Y., "Causes and effects of delays in Malaysian construction industry”, International Journal Project Management, Vol 25 (5), pp. 517-526, (2007)

28. Mahamid, I. Bruland, A. and Dmaidi, N., "Cause of Delay in Road Construction Projects" Management in Engineering, Vol 28 (3), pp. 300-310, (2012)

29. Mansfield, N., "Cause of delay and cost overrun in Nigerian construction propject", International Journal of Project Management, pp. 12 (4), 254 - 60, (1994).

30. Mezher, T. andTawil. W., "Causes of delays in the construction industry in Lebanon" Engineering, Construction and Architectural Management,Vol 5 (3), pp.252-260, (1998)

31. Morris, P. andHough G. W., "The anatomy of major projects", New York: A study of the reality of project management, (1987) 
32. Noulmanee, A., Wachirathamrojn, J., Tantichattanont, P., Sittivijan, P., "Internal causes of delays in highway construction projects in Thailand”, (1999)

33. Odeh, A., "Causes of construction delay: traditional contracts", International journal of Project Management, Volume 1, pp. 67-33, (2002)

34. Ogunlana, S.,Promkuntong, K. aandJearkjirm.V., "Construction delay in a fast - growing economy" comparing Thailand with other economics. International Journal of Project Management, Vol. 14 (1), pp. 37-45, (1996)

35. Olawale, Y., "Cost and time control practice of construction project in the UK", University of the West of England, (2010)

36. Punch, K. F., “Introduction to social research",. In: 2nd, ed. Quantitative and qualitative approaches. London: Sage publications Ltd, (2005)

37. Rabbani, W.,Haseeb, M., Xinhai-Lu. Bibi ,A. Maloof-ud-Dyian, "Problems of projects and effects of delays in the construction industry of Pakistan", Australian Journal of Business and Management Research, Vol 1 (5), pp. 41-50, (2011)

38. Rea, L. M. , “Designing and Conducting Survey Research”, In: 3rd, Ed., (2012)

39. Sibanyama, "An overview of construction claims: A case study of the Zambian construction industry”, The International Journal of Construction Management, pp 65-81, (2012)

40. Sriprasert, E., “Assessment of Cost Control System: A Case Study of Thai Construction”, M.S. thesis, Bangkok: Asian Institute of Technology, (2000)

41. Howick, S., Ackermann, F., Eden, C. and Williams, T., "Understanding the causes and consequences of disruption and delay in complex projects: how system dynamics can help", In, Meyers, R. (ed.) Encyclopedia of Complexity \& Systems Science. Berlin, Springer Verlag, (2009)

42. Van Der Westhuzien, "Defining measuring project success”, University of Quesnland, (2005)

43. Wael, A., Mohd, R.A., Kadir, A.S. and Ernawati, D., "The significant factors causing delay of building construction projects in Malaysia, Engineering”, Construction and Architectural Management, Vol. 14 (2), pp. 192-206, (2007)

44. Yates, J. K. andEpstein. A, "Avoiding and minimizing construction delay claim disputes in relational contracting”, Journal of professional Issies in Engineering Education and practice, Vol. 132(2), pp.168-179, (2006) 
Appendix-A (Source: Doloi, 2013)

\begin{tabular}{|c|c|c|c|c|c|c|c|c|c|}
\hline \multirow[b]{2}{*}{ ID } & \multirow[b]{2}{*}{ Attributes } & \multicolumn{2}{|c|}{ Overall } & \multicolumn{2}{|c|}{ Clients } & \multicolumn{2}{|c|}{ Consultants } & \multicolumn{2}{|c|}{ Contractors } \\
\hline & & $\begin{array}{l}\text { RIW } \\
(\%)\end{array}$ & Ranking & $\begin{array}{l}\text { RIW } \\
(\%)\end{array}$ & Ranking & $\begin{array}{l}\text { RIW } \\
(\%)\end{array}$ & Ranking & $\begin{array}{l}\text { RIW } \\
(\%)\end{array}$ & Ranking \\
\hline $\mathrm{C} 19$ & Planning and scheduling deficiencies & 2.679 & 1 & 2.549 & 3 & 2.652 & 1 & 2.780 & 1 \\
\hline C44 & Effective monitoring and feedback process & 2.632 & 3 & 2.660 & 1 & 2.596 & 3 & 2.642 & 6 \\
\hline $\mathrm{C} 14$ & Complexity of design and construction & 2.586 & 4 & 2.505 & 5 & 2.559 & 5 & 2.656 & 5 \\
\hline C36 & Improper control over site resource allocations & 2.574 & 5 & 2.461 & 7 & 2.540 & 6 & 2.670 & 4 \\
\hline $\mathrm{C} 10$ & $\begin{array}{l}\text { Contractor's deficiencies in planning and scheduling at } \\
\text { tender stage }\end{array}$ & 2.504 & 6 & 2.549 & 4 & 2.485 & 7 & 2.684 & 3 \\
\hline $\mathrm{C} 31$ & Mistakes and discrepancies in construction documentations & 2.429 & 9 & 2.394 & 8 & 2.411 & 9 & 2.615 & 7 \\
\hline C38 & Client-initiated variations & 2.429 & 10 & 2.239 & 18 & 2.336 & 12 & 2.422 & 14 \\
\hline C48 & Staff training in the skill areas relevant to project & 2.405 & 11 & 2.350 & 10 & 2.336 & 13 & 2.491 & 11 \\
\hline $\mathrm{C} 22$ & Cash flow during construction & 2.388 & 12 & 2.328 & 12 & 2.318 & 14 & 2.477 & 12 \\
\hline C11 & Design changes within development period & 2.301 & 13 & 2.017 & 27 & 2.151 & 21 & 2.587 & 8 \\
\hline $\mathrm{C} 21$ & Delays in work approval waiting for information & 2.266 & 14 & 2.217 & 19 & 2.207 & 18 & 2.340 & 17 \\
\hline $\mathrm{C} 3$ & Tender period and market condition & 2.236 & 15 & 1.884 & 35 & 2.299 & 15 & 2.078 & 26 \\
\hline C9 & Poor contract management & 2.114 & 21 & 2.128 & 21 & 1.891 & 30 & 2.147 & 25 \\
\hline C37 & Inadequate contractors experience & 2.108 & 22 & 1.796 & 42 & 2.040 & 26 & 2.353 & 16 \\
\hline $\mathrm{C} 1$ & Scale and scope of project & 2.073 & 23 & 1.906 & 31 & 2.058 & 25 & 2.188 & 24 \\
\hline C41 & Delay in subcontractor's projects & 2.050 & 24 & 2.039 & 26 & 2.373 & 11 & 1.885 & 36 \\
\hline $\mathrm{C} 42$ & Lower labor productivity & 2.050 & 25 & 2.106 & 24 & 2.132 & 22 & 1.954 & 33 \\
\hline $\mathrm{C} 33$ & Labor and management relations & 2.038 & 26 & 1.840 & 40 & 1.873 & 32 & 2.285 & 19 \\
\hline $\mathrm{C} 20$ & Buildability (including on-site prefabrication) & 2.027 & 27 & 1.884 & 36 & 1.836 & 35 & 2.257 & 20 \\
\hline $\mathrm{C} 40$ & Low speed at decision-making, involving all project teams & 2.027 & 28 & 2.039 & 25 & 2.021 & 28 & 2.023 & 30 \\
\hline $\mathrm{C} 26$ & Frequent breakdown of construction equipments & 2.015 & 29 & 1.530 & 46 & 1.854 & 33 & 2.436 & 13 \\
\hline $\mathrm{C} 16$ & Availability and supplies of labor and materials & 1.992 & 30 & 2.283 & 15 & 1.502 & 47 & 2.216 & 21 \\
\hline $\mathrm{C} 13$ & Type of structure & 1.945 & 31 & 2.106 & 23 & 1.724 & 43 & 2.009 & 31 \\
\hline $\mathrm{C} 5$ & Project team's experience in development stages & 1.939 & 32 & 2.305 & 13 & 1.743 & 42 & 2.078 & 27 \\
\hline $\mathrm{C} 12$ & $\begin{array}{l}\text { Lack of communication between design team and clients } \\
\text { in design phase }\end{array}$ & 1.939 & 33 & 2.172 & 20 & 1.891 & 31 & 1.858 & 37 \\
\hline $\mathrm{C} 27$ & Lead times for delivery of materials & 1.928 & 34 & 1.906 & 32 & 2.188 & 20 & 2.395 & 15 \\
\hline
\end{tabular}

Appendix-B (Source: Fugar, 2010)

Relative importance index (RII)

\begin{tabular}{|c|c|c|c|c|c|c|c|}
\hline \multirow[t]{2}{*}{ Factors } & \multicolumn{2}{|c|}{ Clients } & \multicolumn{2}{|c|}{ Contractor } & \multicolumn{2}{|c|}{ Consultant } & \multirow{2}{*}{$\begin{array}{c}\text { Overall } \\
\text { Rank }\end{array}$} \\
\hline & RII & Rank & RII & Rank & RII & Rank & \\
\hline Delay in honouring payment certificates & 0.831 & 1 & 0.932 & 1 & 0.852 & 1 & 1 \\
\hline Underestimation of cost of projects & 0.824 & 2 & 0.845 & 5 & 0.792 & 3 & 2 \\
\hline Underestimation of complexity of projects & 0.784 & 6 & 0.824 & 8 & 0.792 & 3 & 3 \\
\hline Difficulty in accessing Bank credit & 0.797 & 4 & 0.858 & 2 & 0.755 & 9 & 4 \\
\hline Poor supervision & 0.743 & 10 & 0.858 & 2 & 0.773 & 5 & 4 \\
\hline $\begin{array}{l}\text { Underestimation of time for completion by } \\
\text { contractors }\end{array}$ & 0.757 & 8 & 0.764 & 12 & 0.801 & 2 & 6 \\
\hline Shortage of materials & 0.696 & 17 & 0.851 & 4 & 0.759 & 8 & 7 \\
\hline Poor Professional Management & 0.804 & 3 & 0.73 & 17 & 0.764 & 7 & 8 \\
\hline Fluctuation of prices & 0.757 & 8 & 0.811 & 9 & 0.736 & 11 & 8 \\
\hline Poor Site management & 0.797 & 4 & 0.743 & 15 & 0.750 & 10 & 10 \\
\hline Construction methods & 0.743 & 10 & 0.791 & 10 & 0.736 & 11 & 10 \\
\hline Delay in instructions from consultants & 0.709 & 16 & 0.831 & 7 & 0.708 & 17 & 12 \\
\hline Late deliveries of materials & 0.655 & 25 & 0.838 & 6 & 0.731 & 13 & 12 \\
\hline Lack of Programme of Works & 0.730 & 12 & 0.709 & 20 & 0.769 & 6 & 14 \\
\hline Delay by sub-contractors & 0.696 & 17 & 0.791 & 10 & 0.731 & 13 & 14 \\
\hline Poor design & 0.730 & 12 & 0.757 & 14 & 0.727 & 15 & 16 \\
\hline Breakdown of equipments & 0.764 & 7 & 0.743 & 15 & 0.704 & 20 & 17 \\
\hline Client initiated variations & 0.716 & 14 & 0.764 & 12 & 0.708 & 17 & 17 \\
\hline Obtaining permit from municipality & 0.689 & 21 & 0.723 & 19 & 0.676 & 22 & 17 \\
\hline Insufficient communication between parties & 0.662 & 23 & 0.730 & 17 & 0.681 & 21 & 17 \\
\hline Necessary variations & 0.696 & 17 & 0.689 & 22 & 0.667 & 23 & 21 \\
\hline
\end{tabular}

